\title{
OPERATION OF 2+1 ROAD WITH HIGH SHARES OF HEAVY VEHICLES
}

\begin{abstract}
M. KIEĆ ${ }^{1}$
The author investigated traffic flow quality on a new $2+1$ long road bypass with an exceptionally high share of heavy vehicles in order to assess rational limits of heavy vehicle shares in traffic flow, dependent on the length of the $2+1$ road and the number of passing segments in each direction. This paper presents the results of traffic flow quality analyses through the use of empirical and simulation methods for a single $2+1$ road segment with additional passing lanes, as well as for the study of the entire section of the bypass $-2+1$ road. Variables include analysis of travel speed distribution, platoon traffic, and amount of passing maneuvers. Results show that large passing demands lead to very high speeds (over $100 \mathrm{~km} / \mathrm{h}$ ) on segments with additional passing lanes. The conclusions include remarks related to the use and operation of $2+1$ cross-sections with high shares of heavy vehicles.
\end{abstract}

Keywords: $2+1$ road, passing, overtaking, traffic performance, traffic flow, microsimulation model, travel speed, heavy vehicles

\section{INTRODUCTION}

In several countries two-lane (TL) roads are an important supplement to motorways and express roads. Heavy traffic still prevails on some of these roads. Slow-moving vehicles on such roads deteriorate the quality of traffic flow by creating platoons and decreasing speeds. When TL roads pass through small towns and villages, an even larger deterioration of the quality of traffic flow (bottlenecks) regarding capacity and delays takes place, thus decreasing their operational reliability. Therefore, segments of roadways with $2+1$ cross-sections were designed in several places in

\footnotetext{
${ }^{1}$ PhD., Eng., Cracow University of Technology, Faculty of Civil Engineering, ul. Warszawska 24, 31-155 Cracow, Poland, e-mail: mkiec@pk.edu.pl
} 
Poland, mainly on newly built bypasses. Roads with $2+1$ cross-sections, thanks to the $3^{\text {rd }}$ alternating additional lane designated for passing, provide larger possibilities for passing than standard twolane roads, decrease platooning, and increase travel speeds in comparison to TL roads. In these cases benefits can also include a reduction of driver frustration when traveling in platoons on a twolane road without the possibility of passing. Literature review shows that in addition to improving traffic safety and decreasing driver frustration, $2+1$ roads operate effectively with average annual daily traffic (AADT) volumes in the range of 15,000-25,000 AADT, and sometimes even up to 30,000 AADT [12]. Issues related to operating difficulties of $2+1$ roads with high rates of heavy vehicles and impacts of platooning on the operation of $2+1$ sections are rather marginally discussed in papers describing problems of $2+1$ roads.

The aim of this paper is to analyze traffic operation performance of $2+1$ roads based on the example of an existent bypass with a $2+1$ cross-section (on the TL road). This bypass services traffic with an exceptionally high share of heavy vehicles (HV). The high share of HV causes an increase of passing demand and, therefore, road safety hazards (higher speed dispersion, platoons consisting of HV). This paper presents the results of traffic flow quality analyses through the use of empirical and simulation methods. Analyses were carried out in order to assess the operational and rational limits of the HV share, taking into account traffic volume, length of the $2+1 \mathrm{road}$, and the number of passing segments. A high share of heavy vehicles can be a highly influential factor which should be considered when making the choice between $2+1$ and dual roadways.

\section{LITERATURE REVIEW}

The impact of additional passing lanes on the quality of traffic flow is described in literature, from around Europe [2], [4], [7], [8], the USA [1], [3], [5], [12], and also other countries [9], [10], [11]. In all studies reviewed, the authors confirm the improvement of traffic performance following the introduction of additional lanes. Most often, the research focuses on assessing the impact of the presence of passing lanes on platooning (i.e. decreasing the number of vehicles in a platoon), passing rates (i.e. increased with increasing traffic volume), speed (i.e. increase in the speed of traffic on the passing lane) and indicating the minimum length of this section required to achieve noticeable benefits.

An evaluation of benefits of passing lanes in Missouri was conducted by [13]. The authors showed that after the implementation of passing lanes the level of service improved noticeably in terms of average travel speeds and percentage of time spent following. 
In Arkansas, passing lanes' operations focusing on continuously alternating passing lane sections were studied [5]. The authors' findings indicated that the passing lane reduced the percentage of vehicles in platoons by about $14 \%$, with much of that reduction in the first $0.9 \mathrm{mi}(1.4 \mathrm{~km})$ of the passing lane. They also found that passing maneuvers increased along with volume, which may indicate that higher-volume roads could use longer passing lanes. In the state of Montana, a study on the operational benefits of passing lanes on rural two-lane roads was carried out [1]. A significant impact of the presence of passing lanes on the reduction of the percentage of vehicles in platoons was observed: the platooning level decreased by about $30 \%$. Based on German operational analyses of $2+1$ road sections [8], the optimum length of a passing lane in terms of platoon discharge and taking into account traffic volume, longitudinal grade, and a share of heavy vehicles (up to $20 \%$ ) was established. A study of the operation of $2+1$ sections in Korea [10] confirms a decrease in the share of traffic in platoons by about $8 \%$ (i.e. percentage of vehicles in a platoon decreased from $88.7 \%$ upstream to $80.4 \%$ downstream) within a distance range of 1 to $1.2 \mathrm{~km}$. Downstream traffic flow showed a smaller platoon size and also a growth in speed by nearly 20 $\mathrm{km} / \mathrm{h}$ behind the passing lane.

The impact of heavy vehicles on traffic performance is rarely described in literature. In most of the analysis reviewed, the observed share of $\mathrm{HV}$ is taken into consideration as an influential factor and the range of its variability is up to $20 \%$. The results of a simulation analysis from New Zealand [9] were an exception, where the analyzed share of heavy vehicles was up to $30 \%$. It may then be concluded that due to the differences in speed and the dynamic performance of both cars and heavy vehicles, a high share of HV seems to have a significant impact on traffic performance and the effectiveness of the operation of $2+1$ cross-sections.

\section{METHOdOLOGY OF RESEARCH}

Analyses were carried out through the use of a microsimulation model developed in Vissim software and based on empirical research. The results of the empirical research were used for the calibration and validation of the microsimulation model for both the single segment and the $2+1$ road, which consists of segments with additional alternately passing lanes.

\subsection{EMPIRICAL RESEARCH}

Empirical research was carried out on a bypass with a $2+1$ cross-section in the town of Zyrardow [15]. It was selected as the research site from among eight $2+1$ roads due to its traffic and road 
characteristics as well as the problems which were have been plaguing it since its beginnings. These operating problems concerned the composition of traffic flow, i.e. the high share of HV, the widths of the cross-section elements, road safety, the impact of vehicle breakdowns and the related quality of traffic flow. The investigated bypass was built as a part of a national road which functions as a bypass around the city of Warsaw for trucks, and is located at a great distance from the city. As a result, traffic reaches 20,000 vehicles/24h, with the share of heavy vehicles of about $50 \%$ (Fig. 1). There is no automatic speed control on the bypass; the speed limit is set at $90 \mathrm{~km} / \mathrm{h}$ for passenger cars and $70 \mathrm{~km} / \mathrm{h}$ for heavy vehicles.

The bypass consists of ten segments located between roundabouts with alternately passing lanes; 5 in each direction. Two roundabouts at both ends of the bypass and a diamond interchange in the middle count as the three access points of the bypass. The horizontal alignment of the bypass has a small curvature and low grades in the $\pm 2 \%$ range. Horizontal and vertical alignments have no impact on traffic operation.

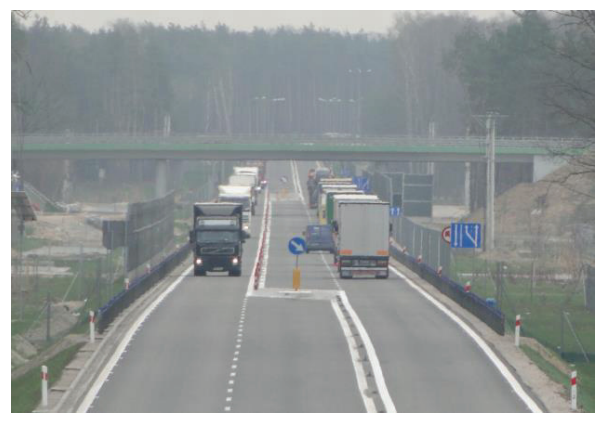

Fig. 1. 2+1 cross-section of the Zyrardow bypass with a high HV share

In order to assess the bypass' traffic operation, several traffic measurements were taken. These covered local and travel speeds, headways, and the share of heavy vehicles present. Pneumatic detectors and an automatic number plate recognition system were used. Measurements were carried out on single $2+1$ segments as well as for the entire section of the bypass located between the roundabouts. The aim of the measurements was to collect data necessary to develop microsimulation model. In total, data was recorded for 15,100 vehicles over a two-day period. The results allowed for an assessment of general traffic parameters on a single segment of road with a passing lane. On the basis of the data from the pneumatic detectors located upstream and 
downstream along 1,350 $\mathrm{m}$ of a passing segment, the effects of platooning and changes in speeds were determined at the point where the additional lane came to an end (Table 1).

The $2+1$ cross-section facilitates faster driving, which is confirmed by the noted increase in speed. Changes were observed for mean speeds of platoon traffic (headways between vehicles not exceeding 3s) and free-flow traffic (headways between vehicles above 6s). High dispersion of passenger cars speeds in comparison with the speeds of heavy vehicles as well as large differences between these two sets of vehicles (Fig. 2) are worth emphasizing. This effect is caused by passenger cars emerging at the end of the passing lane whose speeds are recorded as faster than heavy vehicles leading platoons.

Table 1. Results of traffic statistics for a single segment of the $2+1$ system

\begin{tabular}{|c|c|c|}
\hline & Site 1 - upstream & Site 2 - downstream \\
\hline Length of segment [m] & \multicolumn{2}{|c|}{1350} \\
\hline Average traffic volume [veh/h] & 483 \\
\hline Percentage of heavy vehicles HV\% [\%] & 47.2 & 48.6 \\
\hline Average speed of traffic flow SA [km/h] & 68.4 & 84.1 \\
\hline Speed quantiles 85th S85 [km/h] & 76.9 & 97.4 \\
\hline Speed standard deviation SD [km/h] & 10.4 & 16.65 \\
\hline Speed variability coefficient SD/ SA [-] & 15.22 & 42.1 \\
\hline Share of platoon [\%] & 39.3 & 2.89 \\
\hline Average platoon reduction [\%] & \multicolumn{2}{|c|}{29.01} \\
\hline Size of platoon [veh./platoon] & \multicolumn{2}{|c|}{} \\
\hline Share of vehicles passing [\%] & & 2.72 \\
\hline
\end{tabular}

site 1 - at the begining of a $2+1$ segment

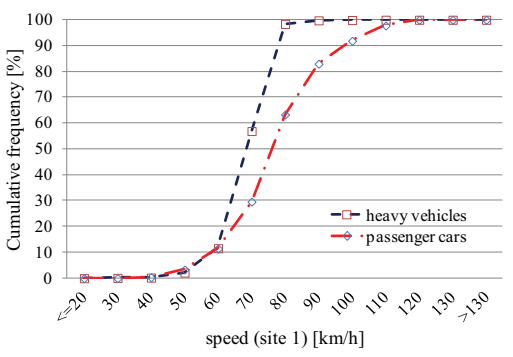

site 2 - at the end of a $2+1$ segment

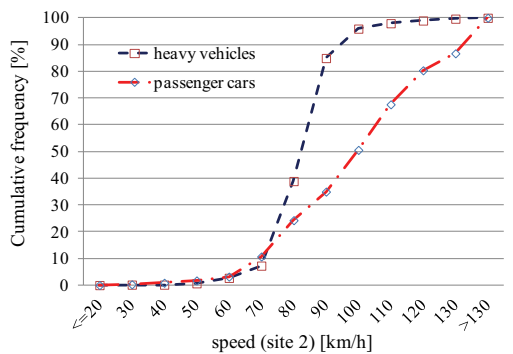

Fig. 2. Cumulative distribution of speeds of vehicles in free-flow at the beginning and at the end of the $2+1$ segment, for passenger cars and heavy vehicles

A very slight change in the platoon traffic share (an increase of $2.85 \%$ ) is accompanied by an about 17 $\%$ reduction in the number of platoons, with a simultaneous $6 \%$ increase in their average size. Despite the presence of long segments of passing lanes on the Zyrardow bypass, the reduction of the platoon 
size is insignificant, due mainly to a large share of heavy vehicles, reaching $50 \%$, as well as a relatively low share of platoon traffic. The empirical measurements recorded an extremely large share of heavy vehicles, reaching on average $48 \%$, and fluctuated in 15 -minute intervals from 35 to $65 \%$, significantly affecting traffic characteristics. Mean speeds of heavy vehicles are lower than those of cars by about $20 \mathrm{~km} / \mathrm{h}$, which can be explained by the designated speed limit as well as the mechanical potential of vehicles.

\subsection{Simulation Model}

A simulation model was developed in VISSIM 5.3. software for one segment of the $2+1$ system and for the $2+1$ road (modelled on the bypass scheme) on the basis of the collected empirical measurements. A graphic representation of the simulation model for one segment is presented in Fig. 3.

The calibration of the simulation model required the use of the cumulative distribution function of speeds in free-flow traffic, both for passenger cars and for heavy vehicles, at the beginning and at the end of the $2+1$ section (measurement sites 1 and 2) (Fig. 2, Fig. 3). In order to achieve the best representation of real-world traffic conditions on the investigated $2+1$ segments, the speed distribution function for vehicles moving in the passing lane was also introduced. In the traffic microsimulation 10 random seeds were considered for each case. Although various values of the Wiedeman parameters were tested, default parameters were used in the microsimulation model.

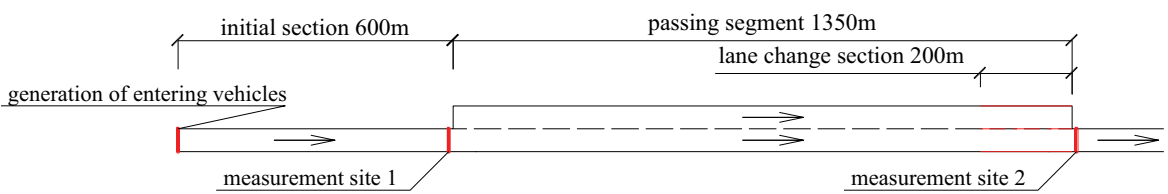

Fig. 3. A scheme of the model of a passing section in VISSIM software

It was assumed that the model was well calibrated and verified under the condition of conformity at an assumed Mean Absolute Percentage Error (MAPE) of below 10\% [14] with the following parameters:

- percent of vehicles in platoons at the beginning and at the end of the $2+1$ segment,

- average platoon size at the beginning and at the end of the $2+1$ segment,

- travel speed for the entire bypass,

- number of passing maneuvers for the entire bypass. 
Table 2 presents a comparison of the share of vehicles in platoons, average platoon size at the beginning and end of the simulated single $2+1$ segment, travel speed, and number of passing maneuvers for the entire bypass $(2+1 \mathrm{road})$. These parameters confirm satisfactory results of the model's validation.

Table 2. Comparison of empirical and simulated results

\begin{tabular}{|c|c|c|c|c|c|c|}
\hline & \multicolumn{3}{|c|}{ Percent of vehicles in platoons [\%] } & \multicolumn{2}{c|}{ Average size of platoon [veh] } \\
\hline & Simulation & Empirical & MAPE [\%] & Simulation & Empirical & MAPE [\%] \\
\hline Beginning of 2+1 section & 39.4 & 39.3 & 0.25 & 2.72 & 2.80 & 2.9 \\
\hline End of 2+1 section & 37.1 & 36.8 & 0.8 & 2.66 & 2.72 & 2.2 \\
\hline & \multicolumn{3}{|c|}{ Average travel speed [km/h] } & \multicolumn{3}{c|}{$\begin{array}{c}\text { Average number of passing maneuvers } \\
\text { [passing/veh] }\end{array}$} \\
\hline & Simulation & Empirical & MAPE [\%] & Simulation & Empirical & MAPE [\%] \\
\hline & 76.5 & 73.5 & 4.1 & 4.7 & 4.3 & 9.3 \\
\hline
\end{tabular}

\section{Simulation Results}

The developed simulation model enabled traffic performance analysis whose aim was to evaluate changes of traffic flow quality for instances of $2+1$ roads with high share of HVs, which is particularly important to the investigated bypass at constraints suggested by [8]. The impact of heavy vehicles was analyzed in the share range of 0 to $60 \%$.

This analysis uses one of the most basic traffic performance measurements of HCM 2010, average travel speeds (ATS). Road class was assumed to be first (I class) based on traffic and geometrical characteristics of the road, and therefore in the evaluation the author decided to forgo analysis based on the percent of time spent following (PTSF), because of a lessened LOS (Level of Service) which describes traffic performance in HCM 2010. Additionally, as an additional traffic performance measure, the number of passing maneuvers was analyzed. The evaluation of the number of passing maneuvers helped identify the percentage of drivers who took advantage of the possibility of passing given by the additional traffic lane, as well as aided in the assessment of the effectiveness of the consecutive $2+1$ segments.

The simulation analyses focused mainly on the impact of heavy vehicles on the value of travel speeds and passing effectiveness based on:

- the evaluation of benefits provided by the $2+1$ cross-section,

- analysis of travel speed changes depending on traffic volumes and HV share of the $2+1$ road analyzed, 
- analysis of traffic flow quality changes for consecutive segments of the $2+1$ road with respect to travel speeds and $\mathrm{HV}$ shares

- analysis of the number of passing maneuvers,

Evaluation of operation for $2+1$ cross-sections has been carried out in comparison to TL crosssections to estimate the potential benefits resulting from the use of the $2+1$ system. Due to some limitations of the simulation model, a lack of possibility of passing along the TL section was assumed, though this simplification proves significant only for low traffic volumes. For large traffic volumes and high shares of heavy vehicles ( $T V>600 \mathrm{veh} / \mathrm{h} /$ direction and $H V>45 \%$ ) the possibility of passing is limited, and traffic operates with a limitation of passing. In conditions such as these, the number of passing maneuvers (based on TL sections under observation before the bypass) is very low and their impact on average speeds is insignificant.

Fig. 4 presents a variation of average travel speeds $\left(A T S_{b}\right)$ along the bypass at traffic volumes of $600 \mathrm{veh} / \mathrm{h} /$ direction and a share of heavy vehicles equal to $45 \%$. It matches the similar conditions under which empirical measurements were conducted. Due to simplification, the results presented in Fig. 4 for TL roads should be used only for a general comparison.

It can be seen from this analysis that at the beginning of the bypass traffic performance [6] can be described by LOS B and D for cross-sections $2+1$ and TL, respectively. At the end of the section of the road with a TL cross-section a LOS E value of $A T S_{b}=58.7 \mathrm{~km} / \mathrm{h}$ was calculated. For the $2+1$ cross-section level C, $A T S_{b}=79.4 \mathrm{~km} / \mathrm{h}$, was estimated. The use of the the $2+1$ cross-section allows for an increase of $A T S_{b}$ by about $20 \mathrm{~km} / \mathrm{h}$.

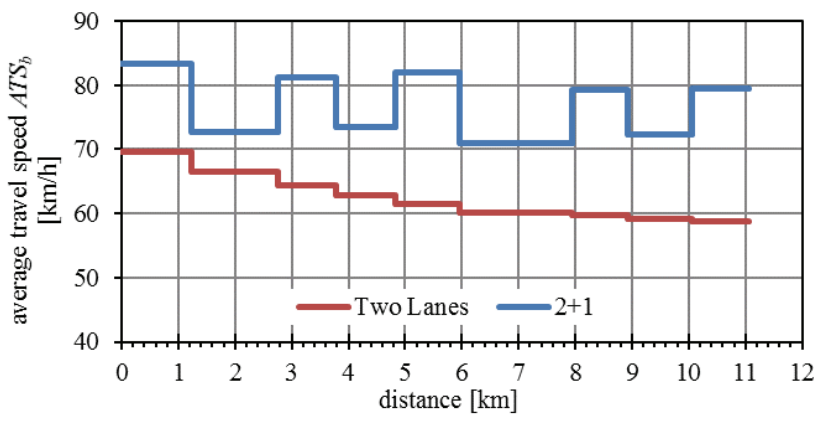

Fig. 4. Comparison of average travel speed values for $2+1$ and two-lane roads

The next step of analysis included the evaluation of travel speed changes for a $2+1$ single segment and a $2+1$ road in relation to TV and HV share. Fig. 5 presents the impact of traffic volumes and 
HV shares on average travel speeds for a $2+1$ single segment $\left(A T S_{s}\right)$ at a length of passing of 1$1,2 \mathrm{~km}$.

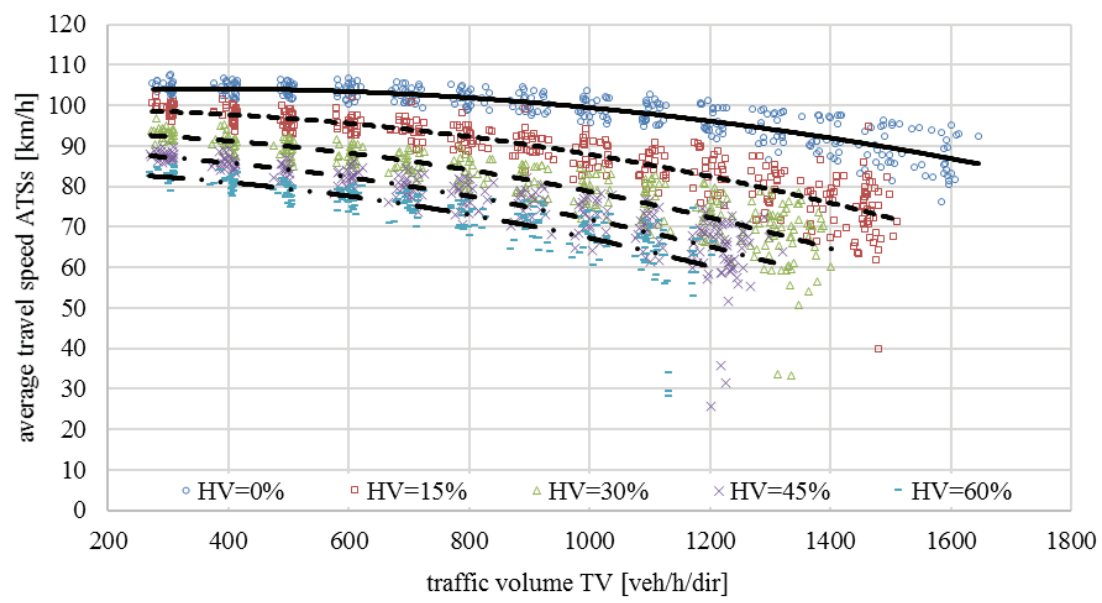

Fig. 5. Impact of traffic volume and share of HV on the average travel speed for a $2+1$ segment An increase in $T V$ (from 300 to $1600 \mathrm{veh} / \mathrm{h} /$ direction) and $H V$ (from $0 \%$ to $60 \%$ ) results in decreased travel speeds. A reduction of the average travel speed for a $2+1$ segment $\left(\triangle A T S_{s}\right)$ depends on the traffic volume and share of heavy vehicles and varies from $20 \%$ (300 veh/h/dir) to $38 \%$ (for high levels of traffic volume, i.e. close to capacity) with respect to base conditions, i.e., when only passenger cars are present $(H V=0 \%)$. The value of speed reduction for a $2+1$ segment may be estimated using the following formula:

$$
\begin{gathered}
\Delta A T S_{s}=-6.3+0.0129 \cdot T V+0.431 \cdot H V[\mathrm{~km} / \mathrm{h}] \\
R^{2}=0.97
\end{gathered}
$$

where:

$\triangle A T S_{s}$ - change of average travel speed for a $2+1$ segment $[\mathrm{km} / \mathrm{h}], T V-$ traffic volume [veh/h/direction], $H V$ - share of heavy vehicles [\%].

Based on the results of the simulation analysis (Fig. 5) the capacity of a given section with an additional passing lane can be estimated. Dependent on the share of heavy vehicles, it is: 1200 $\mathrm{veh} / \mathrm{h}(H V=60 \%), 1320 \mathrm{veh} / \mathrm{h}(H V=45 \%), 1400 \mathrm{veh} / \mathrm{h}(H V=30 \%), 1500 \mathrm{veh} / \mathrm{h}(H V=15 \%)$, and $1650 \mathrm{veh} / \mathrm{h}(H V=0 \%$.) These values are consistent with the results of analyses carried out in other 
countries [2], [6], [9]. However, it should be noted that the research found in this foreign research pertains to roads with a share of heavy vehicles not exceeding $20 \%$.

Similar analysis, including an assessment of traffic flow quality, was carried out for a $2+1$ road. The average value of the travel speed for the $2+1$ road $\left(A T S_{b}\right)$ ranges from $97.4 \mathrm{~km} / \mathrm{h}$ to $61.0 \mathrm{~km} / \mathrm{h}$, dependent on both traffic volume and share of $\mathrm{HV}$, which corresponds to LOS from A to D according to HCM 2010 (Fig. 6). An increase in traffic volume by $100 \mathrm{veh} / \mathrm{h} /$ direction to more than $300 \mathrm{veh} / \mathrm{h} /$ direction causes a reduction in the average travel speed by $1.9 \mathrm{~km} / \mathrm{h}$ (with an insignificant impact of the share of heavy vehicles on this variability). The impact of heavy vehicles on average travel speeds for the entire bypass while in the same range of traffic volume is non-linear, i.e., it is greater for a lower share of heavy vehicles. Changes in average travel speeds $\triangle A T S_{b}[\mathrm{~km} / \mathrm{h}]$ are described by the relationship:

$$
\begin{gathered}
\Delta A T S_{b}=10.2 \cdot \exp ^{-0.022 \cdot H V}[\mathrm{~km} / \mathrm{h}] \\
R^{2}=0.99
\end{gathered}
$$

where:

$\triangle A T S_{b}$ - change of average travel speed for a bypass (2+1 road) $[\mathrm{km} / \mathrm{h}], H V$ - share of heavy vehicles [\%]



Fig. 6. Impact of traffic volume and share of HV on average traffic speeds and LOS on a $2+1$ road

The analyses also includes the variability of average travel speeds for consecutive segments with 2 types of cross-sections, both with an additional traffic lane $(2+1)$ and without it (TL), in order to 
show the variability of traffic flow quality along the whole bypass. Examples of variable values of the average travel speed for the $2+1$ and TL road segments are presented in Fig. 7. The lengths of the passing lanes of the consecutive $2+1$ segments were: $1.2 \mathrm{~km} ; 1.0 \mathrm{~km} ; 1.15 \mathrm{~km} ; 1.0 \mathrm{~km}$, and 1.0 $\mathrm{km}$. These results were collected for an observed traffic volume of $500 \mathrm{veh} / \mathrm{h} / \mathrm{dir}$ and an HV share of $15 \%$ to $60 \%$. The presence of the TL segments results in decreased speeds in the range of 5.4 $\mathrm{km} / \mathrm{h}$ to $17.9 \mathrm{~km} / \mathrm{h}$. This speed reduction depends on the length of the segment and on the share of $\mathrm{HV}$ as well as the traffic volume. The share of heavy vehicles has an essential impact on the value of ATS for each segment, reducing it by $1.7-8.9 \mathrm{~km} / \mathrm{h}$. This impact is greater for $2+1$ roads than for TL segments. A large share of heavy vehicles reduces the possibility of passing slower vehicles, and thus deteriorates flow quality expressed by the average travel speed values. Research indicates that the share of heavy vehicles (especially for a higher share) is a very important factor which should be taken into account when selecting cross-section types of a road.

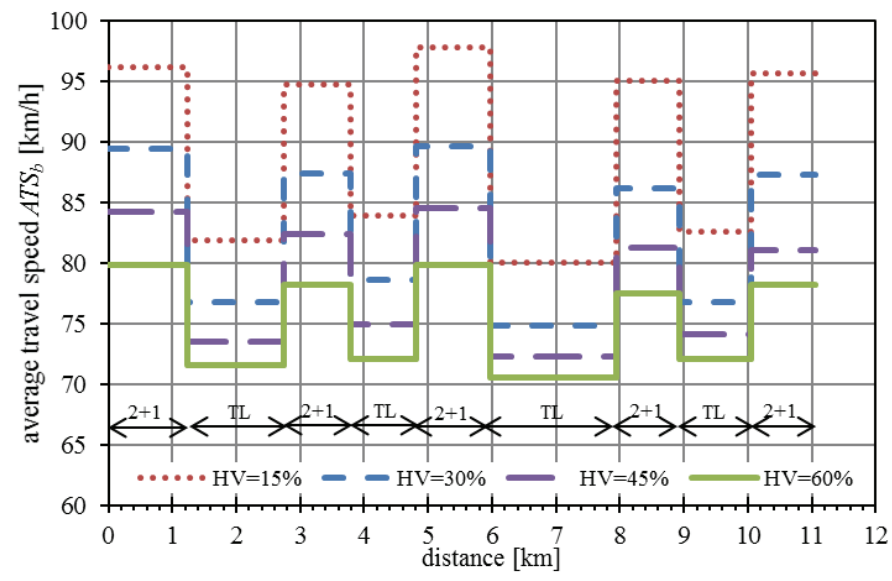

Fig. 7. Impact of the share of heavy vehicles at average travel speeds for a $2+1$ road

One of the main purposes of the implementation of a $2+1$ cross-section is to increase the share of section with the possibility of passing. A high share of heavy vehicles has a particularly significant impact on the feasibility of passing maneuvers. Therefore, in the last step of the research, the possibilities of passing maneuvers dependent on traffic volume and share of heavy vehicles as well as the occurrence of consecutive segments with an additional passing lane were estimated.

Analyses were conducted for a traffic volume range of 300 to $1200 \mathrm{veh} / \mathrm{h} / \mathrm{dir}$. At higher values, disruptions causing problems with credible estimates of passing maneuver numbers were noted. As 
a performance measure, the passing rate $P R$ was introduced; defined as the average number of passing maneuvers per one vehicle in motion.

Fig. 8 presents the impact of traffic volume on the passing rate for a single $2+1$ segment, taking into account different shares of heavy vehicles. The analysis shows the least favorable scenarios when extreme values of the share of heavy vehicles are reported. It may be associated with similar speeds of vehicles, for heavy vehicles and cars, respectively, for the highest and the lowest values of the share of HV. The highest number of passing maneuvers is observed at the share of heavy vehicles of up to $35 \%$. Above this value, a decrease in the $P R$ index and also in average travel speed is noted. Detailed analysis indicates the possibility of efficient operation of $2+1$ sections (regarding passing maneuvers) for $\mathrm{HV}$ even for values over $50 \%$ though, only if traffic volume does not exceed $400 \mathrm{veh} / \mathrm{h} /$ direction. The variability of the $P R$ index is from 0.5 to $1.6 \mathrm{passing} / \mathrm{veh}$, depending on traffic and the share of heavy vehicles.

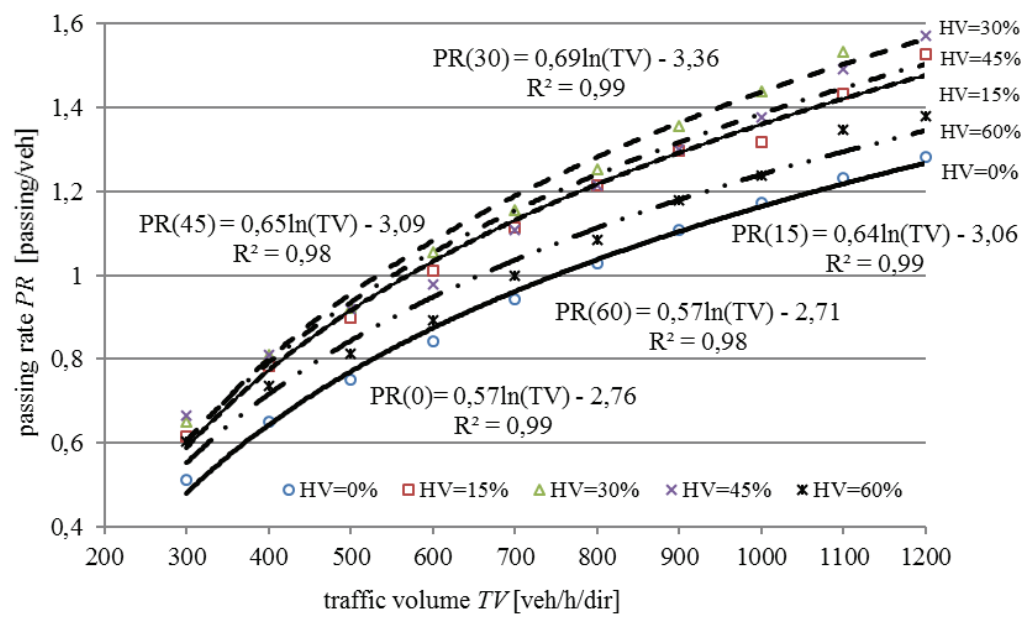

Fig. 8. Impact of traffic volume and share of $\mathrm{HV}$ on the passing rate for a $2+1$ segment

Fig. 3 presents the effect of traffic volume on the number of passing maneuvers per vehicle on a segment for consecutive $2+1$ road sections for an observed share of $\mathrm{HV}$ of about $45 \%$. These results show that passing maneuvers are more often executed on the first 3 segments. Along the length of the 4th and particularly the 5th segment, the number of passing maneuvers is lower, especially at large traffic volumes (>500 veh/h/dir.). At a traffic volume of about $600 \mathrm{veh} / \mathrm{h} / \mathrm{dir}$., the number of passing maneuvers is on average one along the length of each section. The trend of changes in passing efficiency for consecutive $2+1$ segments is independent of the value of the share of HV. 


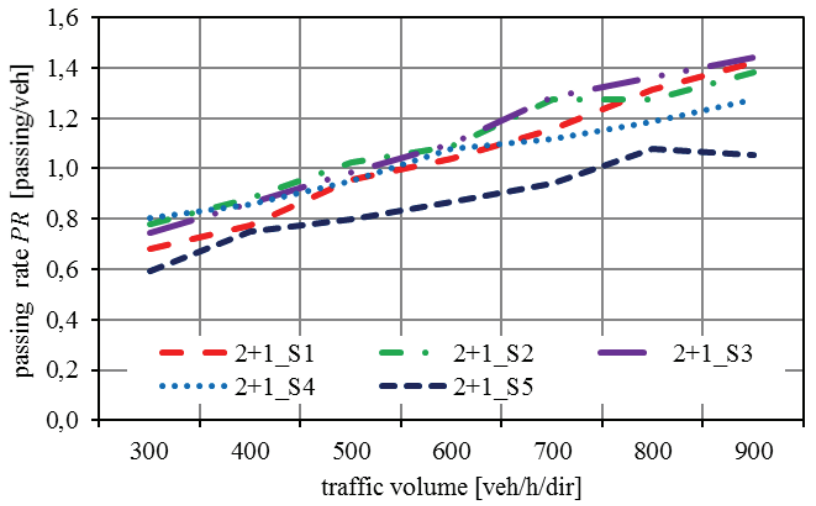

Fig. 9. Impact of traffic volume and the location of a $2+1$ segment on the passing maneuvers rate (Si-i-th $2+1$ segments)

\section{CONCLUSiOnS}

The research carried out by the author concerns a specific case of operation of a $2+1$ road with a high share of heavy vehicles partaking in traffic flow affected also by high speeds of vehicles present. The author decided to evaluate the impact of the presence of these vehicles, though it may not be representative for instances located in other countries. These characteristics of road sections allowed the author to obtain a number of valuable conclusions regarding the design of $2+1$ crosssections.

Simulation studies show a high effectiveness of $2+1$ cross-sections in comparison to two-lane crosssections in terms of travel speed, and allow for the assessment of the impact of heavy vehicle presence on traffic flow quality. An increased share of heavy vehicles significantly decreases overall travel speeds. The trend of changes in average travel speeds depends on traffic volume and is similar to that of multi-lane roads (for $2+1$ segments) and two-lane roads (for $2+1$ road), based on HCM 2010. The estimated capacity values for low shares of heavy vehicles (up to $20 \%$ ) are similar to the results seen in foreign studies. The $2+1$ system seems reasonably effective in comparison to the two-lane bypass regarding traffic volumes of up to 22,000 AADT.

It should be noted that from the point of view of the possibilities for effective passing it is possible to implement $2+1$ cross-sections with high shares of heavy vehicles (up to $35 \%$ ). However, in this case, the share of HV has a significant impact on the reduction of travel speed. The conclusion also indicates that the passing effectiveness decreases in congruence with an increase in the number of 
$2+1$ segments. This research provides grounds for selecting the type of cross-section, whether the $2+1$ road or the dual roadway, right at the design stage.

An important problem on $2+1$ road sections with a high share of heavy vehicles and with high traffic volumes is the merging difficulty before the changeover point, caused by similar speeds of vehicles on the right as well as in passing lanes, and the formation of platoons of heavy vehicles. However, such problems have not been examined in research.

Further research should cover the impact of the length and number of segments with an additional lane. Moreover, their influence on the traffic efficiency of $2+1$ roads in relation to heavy vehicle traffic management (speed limits, enforcing increased headways between heavy vehicles, ITS) requires further attention.

\section{ACKNOWLEDGMENTS}

This paper presents the results of the research projects "Decision support tools in the design and reconstruction of bypasses and roads passing through small towns" (NR10-0067-10) supported by National Centre for Research and Development and "Modern methods of calculating the road capacity and assessment of traffic conditions of roads outside municipal agglomerations, including express roads" (DZP/RID-I-50/9/NCBR/2016) supported by National Centre for Research and Development and General Director for National Roads and Motorways at the part of microsimulation analysis.

\section{REFERENCES}

1. A. Al-Kaisy, Z. Freedman, "Empirical Examination of Passing Lane Operational Benefits on Rural Two-Lane Highways", Procedia-Social and Behavioral Sciences Volume 16. s.1.:s.n., pp. 340-351, 2011.

2. T. Bergh, M. Remgård, A. Carlsson, J. Olstam, P. Strömgren, "2+1-roads Recent Swedish Capacity and Levelof-Service Experience" Transportation Research Procedia, Volume 15, Pages 331-345, 2016.

3. M. Brewer, S. Venglar, K. Fitzpatrick, L. Ding, Park Byung-Jung, "Super 2 Highways in Texas Operational and Safety Characteristics", Transportation Research Record: Journal of the Transportation Research Board vol. 2301., pp. 46-54, 2012.

4. A. Carlsson, "Evaluation of 2+1-roads with cable barrier - final report", VTI rapport 636A, Linkooping: Swedish National Road and Transport Research Institute, 2009.

5. J. L. Gattis, R. Bhave, L. K. Duncan, "Alternating Passing Lane Lengths", Transportation Research Record 1961. TRB. Washington D.C.: National Research Council, pp. pp 16-23, 2006.

6. "Highway Capacity Manual 2010" (HCM2010). Washington D.C.: Transportation Research Board, 2010.

7. L. Herrstedt, "2+1 roads : Danish experiences, Note 5", Danmark: Danmarks Transportforskning, 2001. 
8. M. Irzik, "Layout of 2+1-routes in Germany - New findigs", 4th International Symposium on Hihway Geomteric Design. Valencia, Spain: http://4ishgd.velencia.upv.es/index_archivos/49.pdf, 2010.

9. P. Kirby, G. Koorey, B. Wilmshurst, "Operating characteristics and economic evaluation of $2+1$ lanes with or without intelligent transport systems assisted merging",. NZ transport Agency research report 549: s.n., 2014.

10. S. K. Lee, Y. R. Kim, J. P. Moon, J. S. Choi, "Operational Analysis of 2+1 Roadway and its Use in Deeloping Geomteric Design Standards in S Korea", Valencia, Spain: 4th International Symposium on Highway Geometric Design June 2010, http://www.4ishgd.valencia.upv.es/index archivos/cr7.pdf, 2010.

11. K. Munehiro, et al., "Performance evaluation for rural two-plus-one-lane highway in a cold, snowy region", Transportation Research Record: Journal of the Transportation Research Board, vol. 2272, pp. 161-172, 2012.

12. I. B. Potts, D. Harwood, "Application of European 2+1 Roadway Design", Report Number NCHRP Project 207(139). s.1.:Midwest Research Institue (MRI). Reasearch Result Digest (275), 2003.

13. I. B. Potts, D. Harwood, "Benefits and Design/Location Criteria for Passing Lanes", Report RDT 04-008. Kansas City, MO: Midwest Research Institute, 2004.

14. C. H. Spiegelman, E. S. Park, L. R. Rilett, "Transportation Statistics and Microsimulation", CRC Press, Taylor \& Francis Group, Boca Raton, 2011.

15. M. Tracz, M. Kieć, “Operational problems of 2+1 bypass road sections”, Archives of Transport, vol. 38 (2), pp. 79-89, 2016. 


\section{LIST OF FIGURES AND TABLES:}

Fig. 1. $2+1$ cross-section of the Zyrardow bypass with a high HV share

Rys. 1. Przekrój 2+1 obwodnicy Żyrardowa z dużym udziałem pojazdów ciężkich

Fig. 2. Cumulative distribution of speeds of vehicles in free-flow, at the beginning and at the end of the $2+1$ segment, for passenger cars and heavy vehicles

Rys. 2. Dystrybuanta rozkładu prędkości pojazdów w ruchu swobodnym, na początku i końcu odcinka 2+1 dla pojazdów osobowych i ciężkich

Fig. 3. A scheme of the model of a passing section in VISSIM software

Rys. 3. Schemat modelu odcinka do wyprzedzania w programie VISSIM

Fig. 4. Comparison of the average travel speed values for $2+1$ and two-lane roads

Rys. 4. Porównanie średniej wartości prędkości podróży dla drogi o przekroju dwupasowym i 2+1

Fig. 5. Impact of traffic volume and share of HV on the average travel speed for a $2+1$ segment Rys. 5. Wpływ natężenia ruchu i udziału pojazdów ciężkich na średnią prędkość podróży dla odcinka $2+1$

Fig. 6. Impact of traffic volume and share of HV on average traffic speeds and LOS on a $2+1$ road Rys. 6. Wpływ natężenia ruchu i udziału pojazdów ciężkich na średnią prędkość podróży i poziom swobody ruchu dla drogi $2+1$

Fig. 7. Impact of the share of heavy vehicles at average travel speeds for a $2+1$ road

Rys. 7. Wpływ udziału pojazdów ciężkich na prędkość podróży dla drogi $2+1$

Fig. 8. Impact of traffic volume and share of $\mathrm{HV}$ on the passing rate for a $2+1$ segment

Rys. 8. Wpływ natężenia ruchu i udziału pojazdów ciężkich na wskaźnik wyprzedzeń dla odcinka 2+1

Fig. 9. Impact of traffic volume and the location of a $2+1$ segment on the passing rate $\left(S_{i}-i-t h 2+1\right.$ segments)

Rys. 9. Wpływ natężenia ruchu i lokalizacji odcinka $2+1$ na wskaźnik wyprzedzeń ( $\mathrm{Si}$-kolejny odcinek 2+1) 


\section{FUNKCJONOWANIE DROGI O PRZEKROJU 2+1 Z DUŻYM UDZIALEM POJAZDÓW CIĘŻKICH}

Słowa kluczowe: droga 2+1, wyprzedzanie, warunki ruchu, symulacja, prędkość podróży, pojazd ciężki

\section{STRESZCZENIE:}

W artykule przedstawione zostały badania warunków ruchu na odcinku drogi 2+1, stanowiącym obwodnicę Żyrardowa, z wyjątkowo dużym udziałem pojazdów ciężkich. Celem artykułu była ocena wpływu zmiany udziału pojazdów ciężkich na warunki ruchu dla pojedynczych odcinków $2+1$ jak i dla całego odcinka drogi $2+1$ składającego się $z$ naprzemianległych odcinków z dodatkowym pasem do wyprzedzania.

Przegląd literatury zagranicznej wskazuje na duże korzyści w zakresie funkcjonowania przekrojów 2+1 w odniesieniu do warunków ruchu. W większości opisywanych badań udział pojazdów ciężkich nie przekraczał w warunkach rzeczywistych $20 \%$ lub w symulacyjnych $30 \%$. Obserwacja problemów funkcjonowania obwodnicy Żyrardowa, na której występuje wysoki poziom udziału pojazdów ciężkich spowodowała konieczność podjęcia badań w tym aspekcie. Prace badawcze obejmowały badania empiryczne i analizy symulacyjne. Badania empiryczne realizowane na obwodnicy Żyrardowa obejmowały analizę odcinków z dodatkowym pasem do wyprzedzania oraz całego odcinka drogi $2+1$. Zostały one wykorzystane do wstępnej oceny warunków ruchu oraz jako dane do kalibracji i weryfikacji modelu symulacyjnego.

Model symulacyjny został zbudowany w programie VISSIM 5.3. W celu odwzorowania rzeczywistych zachowań kierujących w ruchu wykorzystano dystrybuanty prędkości pojazdów w ruchu swobodnym dla pojazdów osobowych ciężkich na początku i końcu odcinka z dodatkowym pasem. W procesie kalibracji modelu symulacyjnego testowano różne zestawy parametrów modelu Wieddemana. Ostatecznie wystarczającym okazało się przyjęcie w modelu wartości domyślnych parametrów modelu, co zostało potwierdzone weryfikacją modelu. Do kalibracji i weryfikacji modelu wykorzystano następujące zmienne: udział ruchu kolumnowego, wielkość kolumn pojazdów, prędkość podróży, liczba wyprzedzeń.

W ocenie warunków ruchu jako miernik przyjęto średnią prędkość podróży pojazdów. Jest to miernik stosowany w metodzie HCM 2010 dla dróg dwupasowych z dodatkowym pasem do wyprzedzania. Zrezygnowano ze stosowania drugiego z mierników jakim jest procent czasu jazdy w kolumnie, który stosowany jest głównie do dróg o mniejszym znaczeniu. Dodatkowo w analizach funkcjonowania dróg 2+1 zastosowano wskaźnik wyprzedzania definiowany jako liczba wyprzedzeń przypadająca na jeden pojazd w ruchu. Wskaźnik ten pozwala określić efektywność funkcjonowania drogi o przekroju 2+1 pod względem liczby wyprzedzeń. Analizy symulacyjne obejmowały ocenę wpływu pojazdów ciężkich na prędkość podróży i efektywność wyprzedzania na drodze $2+1$ poprzez:

- porównanie prędkości podróży dla drogi dwupasowej i 2+1 dla obserwowanych danych ruchowych,

- analizę prędkości podróży i wskaźnika wyprzedzeń dla: odcinków z dodatkowym pasem do wyprzedzania, kolejnych odcinków drogi $2+1$ i całej drogi $2+1$,

Porównanie średniej prędkości podróży, dla danych ruchowych obserwowanych w trakcie realizacji pomiarów, dla drogi o przekroju 2+1 (model obwodnicy Żyrardowa) i hipotetycznego odcinka dwupasowej drogi o tej samej długości wskazuje na istotną poprawę warunków ruchu. Średnia prędkość podróży dla drogi $2+1$ jest około $20 \mathrm{~km} / \mathrm{h}$ wyższa.

Analizy symulacyjne zmian prędkości podróży dla odcinka $\mathrm{z}$ dodatkowym pasem i dla drogi $2+1$ przeprowadzono $\mathrm{w}$ zakresie zmienności od 300 do 1600 P/h/kierunek w przypadku natężenia ruchu oraz dla zmienności udziału pojazdów 
ciężkich od 0 do $60 \%$. Górny zakres zmienności udziału pojazdów ciężkich odpowiada szczytowym, obserwowanym wartościom w trakcie realizacji pomiarów.

Ocena zmian prędkości podróży dla odcinka z dodatkowym pasem w zależności od zmian natężenia ruchu i udziału pojazdów ciężkich wskazuje na jej redukcję od 20\% (300 P/h/kierunek) do 38\% (dla natężeń ruchu bliskich przepustowości) w odniesieniu do warunków wyjściowych, tj. występowania w potoku wyłącznie pojazdów osobowych. Trend zmian prędkości jest porównywalny z trendem zmian obserwowanym w metodzie HCM 2010 dla dróg wielopasowych. Wyznaczone wartości przepustowości odcinka z dodatkowym pasem do wyprzedzania na podstawie badań symulacyjnych, wynoszą (w zależności od udziału pojazdów ciężkich) od $1200 \mathrm{P} / \mathrm{h} / \mathrm{kierunek}$ (HV=60\%) poprzez $1320 \mathrm{P} / \mathrm{h} /$ kierunek (HV=45\%), $1400 \mathrm{P} / \mathrm{h} /$ kierunek $(\mathrm{HV}=30 \%)$ i $1500 \mathrm{P} / \mathrm{h} /$ kierunek $(\mathrm{HV}=15 \%)$, do $1650 \mathrm{P} / \mathrm{h} /$ kierunek dla $\mathrm{HV}=0 \%$. Wartości te są zgodne z wynikami analiz przepustowości prowadzonymi w innych krajach. Należy jednak zaznaczyć, że badania zagraniczne dotyczą analiz dróg o udziale pojazdów ciężkich nie przekraczającym $20 \%$.

Zmiana prędkości podróży dla drogi 2+1 ma trend zgodny z wynikami przedstawionymi w metodzie HCM 2010 dla odcinków dróg dwupasowych. Wzrost ruchu o każde $100 \mathrm{P} / \mathrm{h} /$ kierunek, powyżej $300 \mathrm{P} / \mathrm{h} /$ kierunek powoduje spadek prędkości podróży średnio o około $1.9 \mathrm{~km} / \mathrm{h}$, przy mało istotnym wpływie udziału pojazdów ciężkich na tą zmienność). Wpływ udziału pojazdów ciężkich na zmianę wartości średniej prędkości podróży dla drogi $2+1$, w tym samym zakresie natężeń ruchu, jest nieliniowy, tzn. jest większy dla mniejszych wartości udziału pojazdów ciężkich.

Jednym z głównych celów stosowania przekrojów 2+1 jest zwiększenie udziału odcinków z możliwością wyprzedzania, dlatego podjęto analizy zmian wskaźnika wyprzedzeń, które były prowadzone w zakresie natężeń od 300 do $1200 \mathrm{P} / \mathrm{h} /$ kierunek. Powyżej tej wartości występowały zakłócenia nie pozwalające na rzeczywiste oszacowanie liczby wyprzedzeń. $Z$ analiz tych wynika, że najmniej korzystne są największe i najmniejsze wartości udziału pojazdów ciężkich, co jest związane ze zbliżonymi prędkościami pojazdów osobowych i ciężarowych w ruchu. Największa liczba wyprzedzeń realizowana jest przy udziale pojazdów ciężkich wynoszącym do $35 \%$, powyżej tej wartości występuje spadek wyprzedzeń. Należy jednak zwrócić uwagę, na znaczny spadek prędkości podróży przy dużym udziale pojazdów ciężkich. Szczegółowe analizy wskazują na możliwość efektywnego funkcjonowania przekrojów $2+1$ pod względem wyprzedzeń nawet przy udziale pojazdów ciężkich powyżej $50 \%$, jednakże tylko w przypadku natężeń ruchu nie przekraczających $400 \mathrm{P} / \mathrm{h} /$ kierunek. Zmienność wskaźnika wyprzedzeń wyniosła od 0,5 do 1,6 wyprzedzeń/P w zależności od natężenia ruchu i udziału pojazdów ciężkich. Analizując liczbę wyprzedzeń dla kolejnych odcinków drogi 2+1 można wskazać ich zmniejszenie na kolejnych odcinkach z dodatkowym pasem. Zmiana ta jest niezależna od wartości udziału pojazdów ciężkich.

Badania pozwoliły na osiągnięcie wartościowych wyników w zakresie funkcjonowania przekrojów $2+1$ z dużym udziałem pojazdów ciężkich, niespotykane w badaniach zagranicznych. Potwierdzona została wysoka efektywność stosowania przekroju 2+1. Wyniki wskazują na konieczność uwzględnienia w projektowaniu i planowaniu ograniczeń wynikających z dużego udziału pojazdów ciężkich. Czynnik ten powinien być uwzględniany, nie tylko w zakresie warunków ruchu, ale również w zakresie bezpieczeństwa ruchu, które nie było analizowane. Dalsze badania powinny objąć analizę długości i liczby odcinków z dodatkowymi pasami do wyprzedzania oraz możliwość stosowania środków zarządzania ruchem w okresach szczytowych. 